\title{
Mereka yang Keluar dari Rumahnya: Pengalaman Perempuan Madura di Bekasi
}

\author{
Khaerul Umam Noer \\ Universitas Indonesia
}

Abstrak; Sebagai salah satu kelompok etnis yang paling banyak dipelajari di Indonesia terkait dengan mobilitas penduduknya, perempuan sering terabaikan ketika membahas perilaku migrasi Oreng Madura. Tulisan ini akan mencoba untuk menangkap perilaku migrasi perempuan Madura. Secara khusus, migrasi individu oleh perempuan Madura tanpa anggota keluarga mereka dan/atau orang-orang dengan kelompok etnis yang sama di Kabupaten Bekasi. Studi ini mengambil sepuluh orang sebagai subjek, dan berfokus pada mereka yang bekerja sebagai pekerja rumah tangga, pedagang dan pekerja pabrik di beberapa tempat sebagai informan. Secara umum migrasi perempuan Madura di Bekasi mengikuti tiga pola umum: (1) bermigrasi ke tempat di mana ada anggota keluarga, (2) bermigrasi ke tempat di mana tidak ada anggota keluarga namun tetap dalam kelompok etnis yang sama, atau (3) bermigrasi ke tempat yang benar-benar baru. Dalam upaya untuk mengeksplorasi fenomena migrasi individu, tulisan ini berfokus pada poin ketiga. Alasan utama perempuan bermigrasi dari Madura adalah mencari kehidupan yang lebih baik dan mencari kesempatan kerja yang lebih terbuka daripada di daerah asal mereka. Masalahnya adalah, banyak yang tidak memiliki kemampuan yang memadai, sehingga pekerjaan yang tersedia sebagai pekerja rumah tangga dan buruh, namun demikian, pekerjaan tersebut masih diambil sebagai peluang untuk memperoleh penghasilan, baik untuk dirinya sendiri maupun sebagai remitan. Dalam beberapa kasus, mereka tidak lagi kembali ke Madura tetapi memilih untuk tinggal di Bekasi. Tulisan ini berusaha untuk mengeksplorasi alasan bagi perempuan untuk bermigrasi, bagaimana mereka beradaptasi dengan daerah migrasi baru, dan khususnya menjelaskan bahwa perempuan juga sangat kalkulatif dan rasional ketika dihadapkan dengan kondisi ekonomi dan lingkungan yang terbatas.

Kata Kunci: Perempuan, Migrasi, Ekonomi, Madura

Abstract: As one of the most studied ethnic groups in Indonesia related to population mobility, women are often overlooked when discussing the migration behavior of Oreng Madura. This paper will try to capture the migration behavior of Madurese women. Specifically, individual migration by Madurese women without their family members nor people with the same ethnic group in the District of Bekasi. This study takes ten peoples as the subject, and focuses on those who work as household workers, merchants and factory workers in several places as informants. In general it can be said that migration by Madurese women in Bekasi follows three general patterns: (1) 
migrating to a place where there are family members, (2) migrating to places where no family members yet have the same ethnic group, or (3) migrate to a completely new place. In an attempt to explore the phenomenon of individual migration, this paper focuses on the third point. The main reason women migrate to Madurese is to seek a better life and look for more open employment opportunities than in their home regions. The problem is, many do not have adequate capability, so they actually work more as domestic workers and laborers. Nevertheless, the work is still taken as an opportunity to earn income, either for himself or as a remittance. In some cases, they no longer return to Madura but choose to stay in Bekasi. This paper seeks to explore reasons for women to migrate, how they adapt to new migration areas, and in particular is to explain that women are calculative beings when confronted with limited economic and environmental conditions.

Key Words: Women, Migration, Economy, Madura

Korespondensi Penulis:

Khaerul Umam Noer, Pusat Kajian Wanita dan Gender, Universitas Indonesia, Jl. Salemba Raya No. 4, Jakarta Pusat.

E-mail: umam.noer@ui.ac.id

\section{PENDAHULUAN}

Madura merupakan salah satu etnis di Indonesia yang banyak dikaji dari berbagai perspektif. Diantara kajian-kajian tersebut menitikberatkan pada elite agama dan politik (Bruinessen 1995, Mansurnoor 1995, Rozaki 2004, Karim 2004, Julijanti 2009), kebudayaan Madura (lihat Niehof 1992, Bouvier 2002, Wiyata 2002, Rifai 2007, de Jonge 2011) stereotype oreng Madura (de Jonge 1995), historisitas (de Jonge 1989, Kuntowijoyo, 2002, Kasdi 2003) dan migrasi (Sudagung 2001, Fathony 2009, Yogaswara 2012). Sebagai etnis yang banyak dikaji, ada satu persoalan yang mengganjal, utamanya pada kajian migrasi: mengapa wajah migrasi manusia Madura selalu berwajah laki-laki?

Disadari atau tidak, sangat minim - untuk tidak mengatakan tidak ada sama sekali - kajian migrasi yang berfokus pada migrasi perempuan Madura. Kajian-kajian mengenai migrasi yang dilakukan pun umumnya lebih banyak berbicara pada domain 
migrasi yang dilakukan oleh laki-laki untuk mencari nafkah atau penghidupan yang lebih baik bagi dirinya maupun keluarganya, padahal perempuan dan migrasi adalah dua sisi dari mata koin yang sama. Berawal dari hal itulah tulisan ini dibuat dengan mengambil fokus pada migrasi yang dilakukan oleh perempuan Madura di wilayah Kabupaten Bekasi. Secara khusus, tulisan ini memiliki dua tujuan: Pertama, sebagai kritik atas berbagai kajian migrasi yang melupakan perempuan Madura sebagai pelaku migrasi. Kedua, sebagai upaya untuk mendedahkan lebih lanjut bahwa migrasi yang dilakukan oleh perempuan adalah tipe migrasi yang unik yang belum mendapat perhatian serius bagi para peminat kajian migrasi maupun kajian Madura.

\section{MIGRASI PEREMPUAN DAN PENCARIAN KESEMPATAN KERJA}

Dalam banyak kajian, migrasi yang dilakukan oleh perempuan lebih disebabkan oleh terbatasnya kesempatan kerja maupun penyusutan lapangan kerja yang ada (Hugo 1992). Revolusi hijau yang digaungkan oleh pemerintah Indonesia dituding sebagai penyebab menurunnya kesempatan kerja yang miliki oleh perempuan. Collier (1974) misalnya, menuduh revolusi hijau menjadikan perempuan di pedesaan Jawa telah kehilangan pekerjaan mereka, karena pekerjaan mereka justru diambilalih oleh mekanisasi pertanian. Migrasi yang dilakukan, bukan hanya oleh laki-laki namun juga perempuan, di berbagai pedesaan di Jawa nampaknya terkait erat dengan involusi pertanian sebagaimana yang dikemukakan oleh Geertz (1983). Involusi pertanian secara signifikan telah mengubah berbagai pola kerjasama pertanian di pedesaan Jawa, seperti perubahan sistem bawon ke tebasan, perubahan sistem tumbuk ke huller, maupun perubahan sistem maro ke kedokan. Faktor lainnya adalah menurunnya upah di sektor pertanian yang disebabkan kesenjangan antara tekanan penduduk terhadap 
tanah dengan terbatasnya kesempatan kerja di luar sektor pertanian (Kasryno 1983, Soelistiono 1990).

Berbagai faktor tersebut merupakan penyumbang bagi pengambilan keputusan orang untuk melakukan migrasi. Tampak bahwa tidak ada perbedaan alasan maupun tujuan untuk melakukan migrasi, baik yang dilakukan oleh laki-laki maupun perempuan (Hugo 1992). Suharso (1975) pernah membedakan antara tujuan migrasi yang dilakukan oleh laki-laki dengan perempuan. Laki-laki umumnya bermigrasi untuk mencari pekerjaan $(64,5 \%)$, mengikuti orang tua $(11,8 \%)$, menempuh pendidikan $(10,1 \%)$, dan mengikuti keluarga (5\%); sedangkan perempuan melakukan migrasi dengan tujuan untuk mengikuti suami (48,8\%), mencari pekerjaan $(21,5 \%)$, mengikuti keluarga $(13,5 \%)$, dan mengikuti orang tua $(10,1 \%)$. Meskipun demikian, tetap saja muncul pertanyaan, apakah data yang dikemukakan oleh Soeharto masih relevan hingga saat ini atau malah sebaliknya?

Perempuan dan migrasi pada dasarnya adalah satu kesatuan yang tidak dapat dipisahkan (Chant dan Radcliffe 1992). Sebagai sutu sarana mobilitas penduduk, migrasi tidak dapat dilihat hanya dari sudut pandang ekonomi sebagai faktor utama, namun juga harus mempertimbangkan aspek sosial, budaya, bahkan politik (Haris 2002). Migrasi yang dilakukan oleh perempuan umumnya dipicu oleh minimnya kesempatan kerja di daerah asal, atau meminjam istilah Mantra (1989), bahwa besarnya perbedaan tingkat kefaedahan antarwilayah mendorong seseorang untuk melakukan migrasi, baik melalui saluran-saluran yang resmi maupun yang tidak resmi. Tentu saja adanya kesenjangan ini mendorong perempuan untuk berusaha lebih mandiri untuk memperbaiki kehidupannya. 
Di titik ini kita harus melihat pada kondisi ekonomi dan politik yang mendorong terjadinya migrasi perempuan, khususnya perempuan Madura di Kabupaten Bekasi. Jika melihat data migrasi perempuan Madura yang saya miliki (Noer 2006, 2008) kuat dugaan bahwa kedatangan para perempuan migran dari Madura di Kabupaten Bekasi terjadi pada medio 1960-an sampai akhir 1970-an. Hal ini dapat dilihat bahwa pada era 1970-an, partisipasi angkatan kerja dapat dikatakan mencapai 46,8\%, dan semakin meningkat pada tahun 1990 menjadi 53\%. Menurut Tjiptoherijanto (1997:7), peningkatan ini terjadi karena dua hal, yaitu: (1) adanya perubahan struktur umur penduduk, dan (2) peningkatan partisipasi angkatan kerja perempuan. Lalu pertanyaannya adalah, mengapa Bekasi?

Dapat dikatakan bahwa Bekasi merupakan salah satu penyangga Ibu Kota Jakarta, dengan demikian, dinamika kependudukan di Jakarta akan turut berdampak pada dinamika kependudukan di wilayah penyangganya, termasuk diantaranya adalah Bekasi. Jakarta telah menjadi pusat dari migrasi yang dilakukan oleh penduduk Indonesia, di mana pada tahun 1990, 39,9\% penduduknya adalah migran (Tjiptoherijanto, 1997:12). Sebagai salah satu penopang Jakarta, tidak mengherankan jika Bekasi turut terimbas dengan pertambahan penduduk, hanya saja, sangat disayangkan tidak terdapat data yang pasti mengenai pertumbuhan penduduk Bekasi, terutama jumlah migran yang masuk ke wilayah Bekasi.

\section{MIGRASI PEREMPUAN MADURA DI BEKASI}

Dalam kajian yang dilakukan oleh Noer (2006), diketahui bahwa perempuan Madura yang melakukan migrasi tidak datang ke Bekasi sebagai tujuan pokok mereka. Mereka umumnya terlebih dahulu datang ke Jakarta, namun seiring dengan semakin sedikitnya 
kesempatan kerja yang terbuka bagi mereka, akhirnya mereka beralih ke daerah penyangga Jakarta, seperti Depok, Bogor dan Bekasi. Sebagai daerah pusat ekonomi dan pemerintahan, Jakarta merupakan pusat urbanisme di Indonesia (Evers dan Korff 2002), hal ini merupakan magnet yang sangat kuat bagi terjadinya migrasi rural-urban. Munculnya berbagai kota besar di Indonesia pada dasarnya memiliki masalah klasik yang sama, yakni pertumbuhan kota yang sangat pesat ditandai dengan masuknya para migran dari daerah pedesaan (Kanto 2006).

Kedatangan mereka umumnya disertai dengan keluarga mereka, baik itu mereka mengikuti suami atau mengajak anak mereka untuk tinggal bersama dengan mereka. Dalam kajian Noer (2006) diketahui bahwa migrasi yang dilakukan oleh perempuan umumnya ke wilayah yang terdapat sanak keluarga perempuan itu, baik itu ke tempat suami bekerja, atau ke wilayah yang lebih dahulu didatangi oleh anggota keluarga yang menetap di wilayah itu. Penelitian Hanafi (2005) mendapatkan pola lain, bahwa ada pula perempuan yang melakukan migrasi ke Bekasi bukan ke wilayah yang terdapat anggota keluarganya, namun ke daerah yang memiliki etnis yang sama, mereka umumnya mengikuti teman yang sudah terlebih dahulu bekerja di suatu wilayah. Pola ketiga muncul dari Noer $(2007,2008)$ yang mendapatkan adanya perempuan yang datang ke wilayah Bekasi, bukan ke wilayah yang terdapat anggota keluarganya maupun ke wilayah yang terdapat orang dengan etnis yang sama, namun justru ke tempat yang benar-benar baru.

Dengan demikian, terdapat tiga pola dasar yang dapat ditemukan pada para perempuan yang bermigrasi ke Bekasi, yaitu: (1) mereka bermigrasi ke wilayah yang terdapat sanak saudara maupun suami, (2) mereka yang bermigrasi ke wilayah yang tidak terdapat sanak saudara namun terdapat sejumlah orang yang berasal dari etnis 
dan/atau wilayah desa asal yang sama, dan (3) mereka yang bermigrasi ke wilayah yang tidak terdapat sanak saudara maupun orang-orang dengan etnis dan/atau daerah asal yang sama, atau mereka yang bermigrasi ke wilayah yang benar-benar baru. Berdasarkan jumlah orang yang melakukan migrasi, setidaknya terdapat dua macam migran, yaitu: (1) mereka yang bermigrasi secara bersama-sama, atau mereka yang bermigrasi ditemani oleh satu orang teman atau lebih (Hanafi 2005), dan (2) mereka yang bermigrasi secara individual (Noer 2007, 2008). Jika dikaitkan pola laju migrasi, maka didapati bahwa seluruh migran yang datang ke Bekasi adalah migran yang semi menetap (pulang ke kampung halaman setiap enam bulan sampai satu tahun sekali) dan migran menetap (pulang kampung lebih dari tiga tahun sekali).

\section{PARA PELAKU MIGRASI INDIVIDUAL}

Cukup sulit untuk menemukan para perempuan yang menjadi subjek kajian ini, yakni mereka yang melakukan migrasi individual ke tempat yang benar-benar baru bagi mereka. Mayoritas perempuan yang melakukan migrasi selalu ditemani oleh teman atau keluarga, sehingga mencari perempuan Madura yang melakukan migrasi individual seperti mencari jarum dalam tumpukan jerami. Mengingat pembatasan yang dilakukan oleh studi ini, maka peneliti mencari migran yang bermukim berdasarkan informasi dari migran lain, dan begitu migran tersebut ditemukan, maka pengecekan latar belakang dan kondisi lingkungan sekitar menjadi keharusan untuk dilakukan untuk membuktikan bahwa migran tersebut termasuk dalam kriteria ini. Meskipun demikian, sekurangnya terdapat sepuluh orang perempuan yang melakukan migrasi tipe ini, dan karena mereka bermigrasi ke tempat yang tidak ada pihak yang berhubungan saudara dan/atau orang dengan etnis yang sama, maka lokasi kajian ini sangat tersebar di Kabupaten Bekasi. Dari sepuluh orang subjek kajian, tiga orang saat ini menetap di 
Kecamatan Babelan, satu orang menetap di Kecamatan Cikarang Barat, satu orang di Kecamatan Cikarang Timur, dua orang di Kecamatan Tambun, dua orang di Kecamatan Cibitung, satu orang di Kecamatan Setu. Kesepuluh orang tersebut adalah Wardah dari Arosbaya, Bangkalan; Atikah dari Arosbaya, Bangkalan; Maimunah dari Geger, Bangkalan; Sariyah dari Konang, Bangkalan; Mariatun dari Kokop, Bangkalan; Supini dari Tanah Merah, Bangkalan; Saminah dari Pegantenan, Pamekasan; Rukoyah dari Tlanakan, Pamekasan; Jakiyah dari Dungkek, Sumenep; dan Syarifah dari Kalianget, Sumenep.

Tabel 1 Latar Belakang Subjek

\begin{tabular}{|c|c|c|c|c|c|c|c|c|}
\hline Informan & Daerah asal & $\begin{array}{l}\text { Usia } \\
\text { saat } \\
\text { ini }\end{array}$ & $\begin{array}{l}\text { Usia } \\
\text { keluar }\end{array}$ & $\begin{array}{l}\text { Status } \\
\text { ketika } \\
\text { keluar }\end{array}$ & $\begin{array}{l}\text { Informasi } \\
\text { mengenai } \\
\text { pekerjaan }\end{array}$ & $\begin{array}{l}\text { Status } \\
\text { saat ini }\end{array}$ & Asal suami & Domisili \\
\hline Wardah & $\begin{array}{l}\text { Arosbaya, } \\
\text { Bangkalan }\end{array}$ & 40 & 29 & $\begin{array}{l}\text { Janda } \\
\text { cerai }\end{array}$ & Tetangga & Kawin & Pasuruan & Cibitung \\
\hline Atikah & $\begin{array}{l}\text { Arosbaya, } \\
\text { Bangkalan }\end{array}$ & 47 & 32 & $\begin{array}{l}\text { Janda } \\
\text { mati }\end{array}$ & Tetangga & Kawin & Cibitung & $\begin{array}{c}\text { Cikarang } \\
\text { Barat }\end{array}$ \\
\hline Maimunah & $\begin{array}{c}\text { Geger, } \\
\text { Bangkalan }\end{array}$ & 44 & 35 & $\begin{array}{l}\text { Janda } \\
\text { cerai }\end{array}$ & $\begin{array}{l}\text { Kakak } \\
\text { suami }\end{array}$ & Kawin & Majalengka & Setu \\
\hline Sariyah & $\begin{array}{l}\text { Konang, } \\
\text { Bangkalan }\end{array}$ & 35 & 23 & $\begin{array}{l}\text { Belum } \\
\text { kawin }\end{array}$ & Teman & Kawin & Solo & Babelan \\
\hline Mariatun & $\begin{array}{c}\text { Kokop, } \\
\text { Bangkalan }\end{array}$ & 42 & 27 & $\begin{array}{l}\text { Janda } \\
\text { cerai }\end{array}$ & Tetangga & Kawin & Bojonegoro & $\begin{array}{c}\text { Cikarang } \\
\text { Timur }\end{array}$ \\
\hline Supini & $\begin{array}{c}\text { Tanah Merah, } \\
\text { Bangkalan }\end{array}$ & 34 & 22 & $\begin{array}{l}\text { Belum } \\
\text { kawin }\end{array}$ & Teman & Kawin & Tambun & Tambun \\
\hline Saminah & $\begin{array}{l}\text { Pegantenan, } \\
\text { Pamekasan }\end{array}$ & 38 & 23 & $\begin{array}{l}\text { Belum } \\
\text { kawin }\end{array}$ & Teman & Kawin & Blora & Babelan \\
\hline Rukoyah & $\begin{array}{l}\text { Tlanakan, } \\
\text { Pamekasan }\end{array}$ & 46 & 31 & $\begin{array}{c}\text { Janda } \\
\text { mati }\end{array}$ & $\begin{array}{c}\text { Kakak } \\
\text { kandung }\end{array}$ & Kawin & Cibitung & Cibitung \\
\hline Jakiah & $\begin{array}{l}\text { Dungkek, } \\
\text { Sumenep }\end{array}$ & 51 & 33 & $\begin{array}{l}\text { Janda } \\
\text { cerai }\end{array}$ & Kakak ipar & Kawin & Indramayu & Babelan \\
\hline Syarifah & Kalianget & 43 & 29 & $\begin{array}{l}\text { Janda } \\
\text { cerai }\end{array}$ & Tetangga & Kawin & Magetan & Tambun \\
\hline
\end{tabular}




\section{MIGRASI PEREMPUAN: FAKTOR-FAKTOR PENTING}

Sepuluh subjek penelitian ini menggambarkan adanya suatu pola yang bersifat khusus, yakni sebagian dari mereka berasal dari Bangkalan, dan sisanya berasal dari Pamekasan. Mayoritas subjek berasal dari Bangkalan, hal ini menggambarkan bahwa adanya akses yang lebih mudah terhadap transportasi mendorong terjadinya migrasi. Sebagai daerah yang pasti dilalui ketika akan menyebrang ke Surabaya, Bangkalan menjadi kabupaten di Madura yang memiliki sarana transportasi yang paling memadai, hal ini dapat dilihat dengan subjek yang datang dari Bangkalan. Hampir seluruh subjek sepakat, bahwa menemukan orang Madura yang berasal dari Bangkalan di Jakarta dan sekitarnya lebih mudah ketimbang yang berasal dari Sampang, Pamekasan dan Sumenep. Hal ini tentunya sangat mudah mengaitkan antara mobilitas penduduk dengan sarana pendukung mobilitas tersebut. Sebagai daerah yang terjauh, bukannya tidak ada migran yang berasal dari Sumenep, hanya saja jumlahnya sangat sedikit.

Dari beberapa kantung migran Madura yang berada di wilayah Kabupaten Bekasi misalnya, hanya terdapat tiga wilayah yang dihuni oleh migran Sumenep, hal ini jauh berbeda jika dibandingkan yang berasal dari Bangkalan yang mencapai sekurangnya lima belas lokasi, sedangkan yang berasal dari Sampang berjumlah delapan lokasi, dan Pamekasan sebanyak sepuluh lokasi (Hanafi 2005, Noer 2006, 2007). Poin lainnya yang cukup menarik adalah, belum ditemukannya migran perempuan yang melakukan migrasi individual yang berasal dari Sampang. Menurut penuturan Atikah, dahulu ia memiliki teman migran yang berasal dari Sampang, hanya saja ia kemudian menikah dengan laki-laki yang juga berasal dari Sampang kemudian dibawa ke rumah suaminya. Wilayah Sampang merupakan wilayah yang cukup banyak 
mengirimkan migran ke wilayah Kabupaten Bekasi, hanya saja, berdasarkan pengamatan, laki-laki lebih mendominasi secara kuantitas ketimbang perempuan. Hal ini berbeda dengan lokasi tempat tinggal migran yang berasal dari Bangkalan, di mana jumlah laki-laki dan perempuan secara kuantitas seimbang. Saya harus mengakui bahwa tidak ada data resmi yang menyebutkan berapa jumlah pasti migran berdasarkan jenis kelamin maupun daerah asal, namun setidaknya dapat ditarik suatu kesimpulan berdasarkan pengamatan yang berasal dari masing-masing lokasi permukiman migran.

Dapat dilihat bahwa mereka seluruhnya keluar dari Madura pada usia yang relatif muda dan masih dalam usia produktif. Sebagian dari mereka berstatus belum menikah, sedangkan lainnya berstatus janda. Status menjadi poin penting, di mana status yang 'bebas' menjadi pendorong yang sangat efektif bagi perempuan mengambil pilihan untuk melakukan migrasi (Chant dan Radcliffe 1992, Noer 2016). Nampaknya bukan hanya status yang menjadi pendorong bagi terjadinya migrasi, namun juga pekerjaan yang semula mereka tekuni. Sebagai seorang istri, Wardah, Atikah, Maimunah, Mariatun, Rukoyah, Jakiah, dan Syarifah bertugas mengurusi tanean termasuk mengolah ladang - yang dimiliki oleh keluarganya. Sebagai seorang peladang, maka pendapatan yang mereka peroleh sangat fluktuatif, apalagi jika sang suami tidak memiliki pekerjaan tetap. Maka dengan pendapatan yang sedikit dan tidak menentu, mereka harus memutar otak agar rumah tangga mereka tetap dapat berjalan. Berbeda halnya dengan Sariyah, Supini, dan Saminah yang belum menikah. Seluruh subjek merasakan betul betapa terbatasnya lapangan pekerjaan yang mereka miliki, terutama jika dikaitkan dengan jenis kelamin dan status yang mereka miliki. 
Salah satu persoalan utama ketika membahas migrasi perempuan adalah akses terhadap ekonomi. Migrasi jelas tidak hanya membutuhkan niat maupun keberanian, namun juga membutuhkan ekonomi sebagai penopang. Dalam hal ini, faktor akses terhadap ekonomi dikaitkan dengan dua faktor penting, yaitu: biaya perjalanan dan biaya hidup di daerah tujuan. Masalah biaya perjalanan mungkin dapat ditangani dengan mudah, namun biaya untuk hidup yang harus dicermati. Seluruh subjek yang datang jelas memiliki kemampuan ekonomi. Para migran yang berstatus sebagai janda cerai mendapatkan kemampuan ekonomi berdasarkan harta gono-gini atau harta perkawinan, sedangkan yang berstatus janda mati mendapatkan harta waris dari suaminya meskipun jumlahnya tidak seberapa.

Satu hal yang menarik diperhatikan, bahwa para migran yang sudah menikah ini telah mempersiapkan 'bekal' mereka sebelum mereka menjanda. Dalam hal ini mereka telah menyisihkan sebagian kecil uang belanja mereka dalam tabungan pribadi, karena mereka menyadari sepenuhnya bahwa mereka suatu saat akan berpisah dengan suaminya, sehingga ketika mereka benar-benar menjanda dan mendapatkan sejumlah harta dari pihak suami dan keluarganya, mereka sudah benar-benar siap. Berbeda halnya dengan para migran yang belum menikah, yang menopangkan kehidupannya pada orang tuanya. Pada kasus Supini, yang menopang adalah ayahnya; sedangkan Sariyah dan Saminah yang pergi karena akan dijodohkan oleh ayah tirinya, maka sang ibu yang menjadi penopang ekonomi, baik untuk biaya transportasi maupun untuk biaya hidup selama beberapa waktu sampai sang anak mampu untuk mencari nafkah sendiri.

Faktor lain yang juga harus dipertimbangkan dalam mengkaji perilaku migrasi para perempuan adalah informasi yang diperoleh mengenai daerah tujuan dan jenis 
pekerjaan yang tersedia. Sekurangnya terdapat tiga sumber utama, yaitu: (1) tetangga, (2) teman, dan (3) pihak keluarga, apakah itu keluarga suami, kakak kandung, bahkan saudara ipar (lihat Tabel. 1). Selain itu, faktor krusial yang harus dicermati adalah usia para migran yang datang ke wilayah Jakarta dan sekitarnya. Pekerjaan yang tersedia mempertimbangkan dua aspek penting: pendidikan dan usia kerja. Dari sepuluh subjek, hanya Supini dan Sariyah yang telah menyelesaikan pendidikan Sekolah Menengah Pertama (SMP), Wardah dan Saminah berhenti pada kelas II SMP, Mariatun dan Syarifah telah menyelesaikan Sekolah Dasar (SD), Rukoyah dan Maimunah tidak tamat SD, sedangkan Atikah dan Jakiah sama sekali tidak sekolah. Dari sepuluh orang subjek, seluruhnya datang ke Jakarta dan Bekasi pada usia produktif. Atikah barangkali yang paling tua, ia datang ketika berusia 35 tahun; sedangkan Supini berusia paling muda, yakni 22 tahun. Hal ini tentu saja dapat dipahami, terutama jika dikaitkan dengan lokasi tempat mereka bermukim. Seluruh subjek bermukim tidak jauh dari tempat pekerjaan mereka. Wardah, Sariyah, Mariatun, Saminah, dan Syarifah bekerja sebagai buruh pabrik; Supini bekerja sebagai pegawai di sebuah supermarket; Maimunah dan Jakiah bekerja sebagai pedagang sayur dan buah; sedangkan Atikah dan Rukoyah bekerja sebagai Pekerja Rumah Tangga.

Jika diperhatikan dengan seksama, terdapat korelasi antara usia dengan jenis pekerjaan yang ditempuh. Supini yang saat ini baru berusia 28 tahun bekerja sebagai kasir di salah satu supermarket besar di daerah Tambun, sedangkan mereka yang berusia antara 29-37 tahun berprofesi sebagai buruh di beberapa pabrik yang ada di sekitar tempat mereka tinggal, dan antara rentang usia 38-45 tahun bekerja secara paruh waktu. Maimunah menjadi pedangan sayur-sayuran di Pasar Setu pada pagi hari, dengan Jakiyah berdagang sayur dan buah di pasar Babelan pada sore dan malam hari. 
Atikah dan Rukoyah menjadi PRT paruh waktu, jam kerja mereka hanya dari pagi hingga siang hari, dan sore harinya mereka menjadi kuli cuci pakaian bagi para tetangga sekitarnya.

Usia dalam hal ini menjadi faktor lain yang menjadi pertimbangan para migran untuk melakukan suatu pekerjaan (Chant dan Radcliffe 1992), tentunya faktor lain adalah ketersediaan lapangan pekerjaan. Hampir sebagian besar pabrik yang ada di wilayah Bekasi menjadikan usia sebagai salah satu referensi mereka ketika merekrut pegawai. Menurut pengakuan Sariyah, tempat dia bekerja, yakni sebuah pabrik pengolahan mie instan, tidak menerima pekerja baru yang berusia di atas 30 tahun. Hal sama juga diakui oleh Wardah, menurutnya, pabrik tempat dia bekerja hanya mempekerjakan mereka yang berusia di bawah 35 tahun. Konsekuensinya, sebagaimana yang diakui Wardah, ia harus memikirkan kemana ia akan bekerja setelah kontraknya secara selesai. Setidaknya nasib yang lebih baik diterima oleh Mariatun dan Syarifah, pabrik tempatnya pekerja membatasi usia pekerjanya maksimal 42 tahun. Berbeda dengan mereka yang bekerja sebagai buruh di pabrik, Supini tidak terlalu merisaukan mengenai pekerjaannya, sebab posisinya sebagai kasir dapat dijabatnya sampai ia berusia 30 tahun, dan setelah itu ia masih dapat bekerja di bagian lain sampai berusia 35 tahun. Agaknya yang tidak merisaukan masalah usia dan pekerjaan hanya Atikah, Maimunah, Rukoyah, dan Jakiah.

Persoalannya adalah, para migran ini tidak mendapatkan penghasilan yang memadai. Keadaan ini menggambarkan adanya perbedaan besaran pengahasilan yang dibedakan berdasarkan jenis kelamin, hal ini yang membuat posisi perempuan yang berperan dalam dunia ekonomi justru terpinggirkan (Susanti 2005). Mereka yang bekerja sebagai buruh di pabrik mendapatkan gaji pokok (tahun 2012) dengan rentang 
antara Rp.1.850.000-Rp.2.150.000/bulan, Supini mendapatkan gaji pokok sebesar Rp.1.800.000/bulan, Atikah dan Rukoyah rata-rata mendapatkan gaji dari bekerja sebagai PRT dan kuli cuci sebesar Rp.1.600.000/bulan, sedangkan Maimunah dan Jakiah mendapatkan penghasilan berdagang rata-rata Rp.3.000.000/bulan. Dari gambaran pendapatan jelas terlihat bahwa Maimunah dan Jakiah mendapatkan pemasukan yang paling banyak, sedangkan Mariatun mendapatkan pendapatan yang paling kecil, hanya sebesar Rp.1.500.000/bulan. Penghasilan tersebut harus mereka pergunakan untuk kebutuhan sehari-hari, biaya pendidikan anak-anak, hingga dijadikan sebagai remiten.

Di antara sepuluh orang subjek, enam orang subjek masih mengirimkan uang ke kampung halaman sebagai remiten, yakni Wardah, Maimunah, Sariyah, Supini, Jakiah, dan Syarifah. Besarannya pun bervariasi, mereka umumnya mengirimkan remiten sekali setiap tahunnya. Farida, Sariyah, Supini, dan Syarifah mengirimkan Rp.2.500.000/tahun, sedangkan Maimunah dan Jakiah mengirimkan Rp.4.000.000/tahun. Hal ini masih ditambah lagi jika mereka harus berlebaran ke kampung halaman, mereka jelas harus menyisihkan uang lebih banyak lagi untuk keluarga mereka. Remitensi ini secara rutin mereka kirimkan, baik dengan datang sendiri ketika berlebaran maupun dititipkan ke saudara atau kenalan yang masih satu kampung dengan mereka. Selain uang, terkadang mereka juga mengirimkan perhiasan emas, utamanya cincin atau gelang yang dikirimkan khusus untuk orangtua di kampung.

Bagi saya, remitensi ini menjadi faktor yang sangat krusial dalam memahami migrasi yang dilakukan oleh para subjek. Jika dilihat secara umum, rata-rata mereka sudah berada di Bekasi lebih dari satu dekade, bahkan mereka telah menikah kembali dengan orang pilihannya sendiri yang bukan berasal dari etnis Madura. Dapat dikatakan bahwa mereka telah memiliki kehidupan yang nyaman yang di Bekasi. Meskipun 
demikian, bagi mereka, Bekasi bukanlah rumah mereka. Madura adalah rumah mereka, tempat mereka kembali (Noer 2016). Hal inilah yang menyebabkan mereka selalu terikat dengan Madura, fakta bahwa mereka sudah ber-KTP Bekasi, tinggal di Bekasi, berinteraksi dengan masyarakat Bekasi, bahkan sudah kehilangan logat Madura, tidak berarti apa-apa bagi mereka. Rumah (baca: Madura) adalah faktor penting yang tidak diabaikan dalam memahami kompleksitas persoalan perempuan dan migrasi.

\section{MENGAPA MEREKA PERGI?}

Sebagai kajian migrasi, tulisan ini mencoba menggambarkan, bahwa perempuan Madura memiliki kalkulasi yang sama dengan laki-laki. Ekonomi menjadi salah satu motif yang mendasarkan pilihan perempuan untuk melakukan migrasi. Meskipun demikian, adalah keliru dengan mengatakan bahwa ekonomi adalah satu-satunya faktor. Sebab alasan kalkulasi ekonomi selain didasarkan pada asumsi rasionalitas universal yang mendorong setiap orang untuk bergerak ke arah yang sama tanpa mempertimbangkan elemen penting: gender. Gender memainkan peran penting tentang bagaimana keputusan perempuan untuk melakukan migrasi (Noer 2011).

Dalam memahami migrasi individual yang dilakukan oleh perempuan Madura, mau tidak mau kita harus melihat dalam konteks kultural (termasuk ekologis) Madura dan dinamika pembangunan pada masa itu. Selain itu, penting pula untuk memahami, bahwa migrasi yang dilakukan oleh perempuan memiliki dimensi yang - sedikit banyak - berbeda dengan migrasi yang dilakukan oleh laki-laki. Terdapat hambatan kultural yang menyebabkan pilihan perempuan untuk melakukan migrasi tidak seluas pilihan yang dimiliki oleh laki-laki. Dalam hal ini, menjadi krusial untuk memahami bagaimana faktor internal dan eksternal dari setiap perempuan yang memilih untuk melakukan migrasi individual. 
Sekurangnya terdapat lima faktor yang mempengaruhi keputusan perempuan untuk melakukan migrasi individual, yaitu: (1) kalkulasi ekonomi, (2) usia, (3) status perkawinan, (4) kemudahan sarana transportasi, dan (5) informasi mengenai lapangan pekerjaan. Pada point pertama jelas terlihat bahwa kemampuan ekonomi mendorong para subjek untuk dapat keluar dari Madura dan merantau untuk mendapatkan kehidupan yang lebih baik. Faktor usia dan jenis lapangan pekerjaan nampaknya saling berkaitan, di mana informasi yang umumnya di dapat adalah tersedianya lapangan pekerjaan bagi mereka yang belum berusia 30 tahun. Hal ini tentu saja mendorong perempuan dengan usia yang jauh lebih muda untuk keluar dari Madura ketimbang mereka yang sudah berusia di atas 30 tahun, yang mana lapangan pekerjaan yang tersedia bagi mereka tidak sebanyak bagi mereka yang berusia di bawah 35 tahun. Faktor lainnya adalah kemudahan sarana transportasi, hal ini mudah dilihat sebab keputusan untuk bermigrasi terkait erat dengan kemudahan sarana transportasi untuk mendukung mobilitas perpindahan penduduk dari satu wilayah ke wilayah lainnya.

Status perkawinan memainkan peran yang penting untuk mendorong perempuan melakukan migrasi individual. Secara sederhana, tidak mungkin bagi seorang yang masih berstatus menikah untuk melakukan migrasi individual, dengan demikian kesempatan ini hanya terbuka bagi mereka yang memiliki status belum menikah atau janda. Status perkawinan menjadi poin yang sangat krusial mengingat budaya orang Madura yang sangat memproteksi perempuan, di mana laki-laki Madura, terutama para suami, sangat protektif terhadap para istri mereka, sehingga hal ini membatasi gerak istri untuk memperoleh pekerjaan. Ketika mereka bercerai atau menjanda karena suami meninggal (tentunya dengan satu syarat bahwa istri tidak 'turun ranjang' atau menikah dengan adik suami agar menjaga ikatan perkawinan). 
Migrasi individual yang dilaksanakan pun seringkali terbentur pada persoalan lapangan pekerjaan yang tersedia. Lapangan kerja yang tersedia bagi perempuan di wilayah Bekasi sebenarnya cukup luas, hanya saja - sebagaimana telah banyak diteliti lapangan pekerjaan tersebut umumnya memberikan gaji yang lebih rendah ketimbang yang diterima oleh laki-laki meskipun dengan jam kerja dan beban pekerjaan yang sama. Persoalan ini merupakan persoalan klasik yang terus membayangi para buruh perempuan, di mana mereka dengan gaji yang relatif rendah dan adanya kekhawatiran terjadinya tindak pelecehan seksual bagi mereka. Meskipun demikian, tidak semua migran individual bekerja sebagai buruh, sebagaimana telah ditunjukkan, bahwa pekerjaan yang mereka lakukan terkait erat dengan usia mereka saat ini. Dengan pendapatan yang rendah, dan adanya tekanan bagi sebagian migran individual untuk mengirimkan remiten bagi keluarga di Madura, maka mereka pun harus melakukan beberapa langkah strategis untuk menjaga keberlangsungan hidupnya di Bekasi. Setidaknya terdapat tiga upaya yang dilakukan, yaitu: (1) tinggal di wilayah yang tidak jauh dari tempat kerja, (2) mengirimkan remiten, dan (3) menikah dengan penduduk sekitar atau dengan orang daerah lain yang bertempat tinggal tidak jauh dari tempat bekerja.

Migrasi individual yang dilakukan oleh para perempuan Madura ini memberikan gambaran mengenai kompleksitas permasalahan perempuan, di mana masalah migrasi ini jelas tidak hanya berkaitan dengan faktor ekonomi, namun juga terkait dengan faktor sosial dan budaya. Sebagai sebuah studi, migrasi individual ini memberikan gambaran betapa usaha perempuan untuk mempertahankan eksistensinya di tengah pilihan yang terbatas. Satu hal yang harus dicatat, bahwa semua subjek mengakui, bahwa mereka sama sekali tidak menyesal ketika harus meninggalkan kampungnya 
untuk bermigrasi di Bekasi, setidaknya hal ini dapat dilihat dalam pandangan Syarifah bahwa migrasi dapat "membuat saya bernapas lebih lega" dan menciptakan pilihanpilihan yang "lebih banyak ketimbang di daerah asli saya." Semoga apa yang diharapkan oleh para perempuan ini bukan mimpi di siang hari, meskipun tantangan yang harus mereka hadapi di Bekasi tidak lebih ringan dibandingkan daerah asal mereka.

\section{Catatan:}

Makalah ini adalah perbaikan menyeluruh dari tulisan saya dalam Seminar Nasional 'Madura dalam kacamata sosial,budaya, ekonomi, agama, kebahasaan, dan pertanian' yang diselenggarakan oleh Puslit Budaya dan Potensi Madura, Universitas Trunojoyo Madura tanggal 12 November 2014. Saya mengucapkan terima kasih kepada Ani Rufaida dan Prasanti Sastrowidjojo atas pandangannya yang menarik atas draft awal naskah ini. Kajian lebih mendalam mengenai migrasi perempuan Madura dapat dilihat dalam disertasi penulis (Noer 2016).

\section{REFERENSI}

Bouvier, H. 2002. Lèbur! Seni Musik dan Pertunjukan dalam Masyarakat Madura. Jakarta: Obor.

Bruinessen, M. van. 1995. "Tarekat and tarekat teachers in Madurese Society", dalam K. van Dijk, H. de Jonge dan E. Touwen-Bouwsma (eds.) Across Madura Strait: The Dynamics of an Insular Society. Leiden: KITLV Press. Hlm. 91-118.

Chant, S. dan S.A. Radcliffe. 1992. "Migration and development: the importance of gender" dalam S. Chant (ed.) Gender \& Migration in Developing Countries. London: Belhaven Press. HIm. 1-29.

Evers, HD dan R. Korff. 2002. Urbanisme di Asia Tenggara, Makna dan Kekuasaan dalam Ruang-Ruang Sosial. Jakarta: Yayasan Obor Indonesia.

Fathony, B. 2009. Pola Pemukiman Masyarakat Madura di Pegunungan Buring. Malang: Intimedia.

Geertz, C. 1983. Involusi Pertanian: Proses Perubahan Ekologi di Indonesia. Jakarta: Bhratara Karya Aksara.

Haris, A. 2002. Memburu Ringgit, Membagi Kemiskinan; fakta di balik migrasi orang Sasak ke Malaysia. Yogyakarta: Pustaka Pelajar. 
Hugo, G. 1992. "Women on the move: changing patterns of population movement of women in Indonesia" dalam Sylvia Chant (ed.) Gender \& Migration in Developing Countries. London: Belhaven Press. Hlm. 174-196.

Jonge, H. De. 1989. Madura dalam Empat Zaman: Pedagang, Perkembangan Ekonomi dan Islam. Jakarta: Gramedia.

1995. "Stereotypes of the Madurese", dalam K. van Dijk, H. de Jonge dan E. Touwen-Bouwsma (eds.) Across Madura Strait: The Dynamics of an Insular Society. Leiden: KITLV Press. Hlm. 7-24.

2011. Garam, Kekerasan dan Aduan Sapi: Esai-Esai tentang Orang Madura dan Kebudayaan Madura. Yogyakarta: LKiS.

Julijanti, D.M. 2009. "Potret Nyai Salimah Hadi sebagai Pemimpin Publik di Madura" dalam S.H. Sastriani (ed.) Gender and Politics. Yogyakarta: Pusat Studi Wanita Universitas Gadjah Mada bekerjasama dengan Penerbit Tiara Wacana. Hlm. 378-389.

Kanto, S. 2006. Sirkulasi dan Komutasi dari Desa ke Kota. Malang: U.P Fakultas Pertanian Universitas Brawijaya.

Karim, A.D. 2004. Pemimpin Wanita Madura. Surabaya: Papyrus.

Kasdi, A. 2003. Perlawanan Penguasa Madura Atas Hegemoni Jawa: Relasi Pusat-Daerah Pada Periode Akhir Mataram (1726-1745). Yogyakarta: Jendela.

Kasryno. 1980. Perkembangan Penyerapan Tenaga Kerja Pertanian dan Tingkat Upah. Laporan Studi Agro Ekonomi.

Kuntowijoyo. 2002. Perubahan Sosial dalam Masyarakat Agraris Madura 1850-1940. Yogjakarta: Mata Bangsa.

Mantra, I.B. 1989. Mobilitas Pendudk Sirkuler dari Desa ke Kota Kecil di Indonesia. Yogyakarta: PPK UGM.

Mansurnoor, I.A. 1995. "Rato and Kiai in Madura: Are they twins?", dalam K. van Dijk, H. de Jonge dan E. Touwen-Bouwsma (eds.) Across Madura Strait: The Dynamics of an Insular Society. Leiden: KITLV Press. Hlm. 25-48.

Mazumbar. 1981. Wages and Employment in Indonesia. Washington: World Bank.

Niehof, A. 1992. "Madurese women as brides and wives", dalam E. Locher-Scholten dan A. Niehof (eds.) Indonesian Women In Focus. Leiden: KITLV Press. HIm. 166-180.

Noer, K.U. 2006. Keluarga Madura di Bekasi: Masalah atau Solusi?. Makalah disampaikan dalam Seminar Sehari "Merumuskan Kembali Pembangunan di Bekasi", diselenggarakan oleh Nuruttaqwa Foundation, Aula KH. Noer Alie Islamic Center Bekasi, 1 Maret.

2007. Migrasi Perempuan Madura di Bekasi: Alasan dan Latar Belakang. Makalah disampaikan dalam seminar "Perempuan dan Dunia Kerja, 
Mempertanyakan Kembali Makna Hari Kartini", diselenggarakan oleh Nuruttaqwa Foundation dan Pondok Pesantren Attaqwa Putri, Pendopo Tamu Pondok Pesantren Attaqwa Putri, 21 April

2008. Hanya laki-laki yang bermigrasi? Benarkah? Meninjau ulang perilaku migrasi etnis Madura di Kabupaten Bekasi. Makalah disampaikan dalam Simposium Jurnal Antropologi Indonesia "The Future of Indonesia: Sustainable Development and Local Initiative in the Post-Capitalist Era", diselenggarakan oleh Jurnal Antropologi Indonesia dan Universitas Lambung Mangkurat, Banjarmasin 22-26 Juli 2008.

2011. "Meninjau Ulang Teori Migrasi, di mana Posisi Perempuan? Kritik, Tawaran, dan Implikasi”, Jurnal Antropologi Indonesia 31(3):160-184.

2016. Tubuh yang terbuang: Perempuan, Keterusiran, dan Perebutan Hak Atas Tanean. Jakarta: Pusat Kajian Wanita dan Gender Universitas Indonesia.

Rifai, M.A. 2007. Manusia Madura. Yogyakarta: Pilar Media.

Rozaki, A. 2004. Menabur Kharisma Menuai Kuasa, Kiprah Kiai dan Blater Sebagai Rezim Kembar di Madura. Yogyakarta: Pustaka Marwa.

Soelistiono, T.D. 1990. Pola Migrasi Buruh Bangunan. Skripsi sarjana tidak dipublikasikan. Surabaya: FISIP Universitas Airlangga.

Sudagung, H.S. 2001. Mengurai Pertikaian Etnis: Migrasi Swakarsa Etnis Madura ke Kalimantan Barat. Jakarta: Institut Studi Arus Informasi.

Suharso et.al. 1975. Migration and Education in Jakarta. Jakarta: Leknas LIPI.

Tjiptoherijanto, P. 1997. Migrasi, Urbanisasi, dan Pasar Kerja di Indonesia. Jakarta: UI Press.

Wiyata, A.L. 2002. Carok: Konflik Kekerasan dan Harga Diri Orang Madura. Yogyakarta: LkiS.

Yogaswara, H. 2012. Meneruskan Hidup Setelah Kerusuhan: Ingatan Kolektif dan Identitas Etnis Madura Pasca Kekerasan Antaretnis di Kota Sampit, Kalimantan Tengah. Disertasi tidak dipublikasikan. Depok: Antropologi FISIP UI. 